\title{
Atividade dos genes relacionados à pluripotência em ovinos
}

\author{
[Activity of pluripotency-associated genes in sheep]
}

\section{"Revisão/Review"}

\author{
Priscila Germany Côrrea Silva, Marcelo Tigre Moura*, Valeska Andrea Ático Braga, José Carlos Ferreira- \\ Silva, Pabola Santos Nascimento, Ludymila Furtado Cantanhêde, Maiana Silva Chaves, \\ Marcos Antonio Lemos Oliveira
}

Laboratório de Biotécnicas Reprodutivas, Universidade Federal Rural de Pernambuco, Recife-PE, Brasil.

*Autor para correspondência/Corresponding author: E-mail: marcelotmoura@gmail.com

\begin{abstract}
Resumo
Embriões antes da implantação possuem células pluripotentes, ou seja, células que apresentam a capacidade de se diferenciar em todos os tecidos que compõem o feto. O controle da pluripotência em nível molecular é estabelecido por diversos fatores, entre eles, os genes relacionados à pluripotência (GRPs). Estes genes contribuem para inibição do processo de diferenciação celular e manutenção da viabilidade de células pluripotentes. No entanto, apesar do crescente conhecimento sobre as funções dos GRPs em camundongos e humanos, pouco se conhece sobre a expressão espaço-temporal e funções dos GRPs em outras espécies, incluindo ovinos. Evidências em bovinos, humanos e camundongos demonstram que GRPs podem apresentar mecanismos de ação diferentes entre as espécies. O objetivo da revisão foi analisar a atividade dos GRPs em ovinos através do perfil de expressão espaço-temporal e funções, bem como apresentar alternativas para acelerar o entendimento da pluripotência na espécie.
\end{abstract}

Palavras-Chave: Ovis aries; totipotência; embriogênese; embriologia.

\begin{abstract}
Embryos before implantation have pluripotent cells, namely, cells that hold the capacity to differentiate into all cell types that form the fetus. Pluripotency is controlled at the molecular level by several factors, and among them, pluripotency-associated genes (PAG). These genes contribute to inhibition of cell differentiation and maintenance of pluripotent cell viability. However, despite growing understanding of PAG roles in mice and humans, less is known about their spatiotemporal expression and roles in other species, including sheep. Evidences in cattle, humans and mice demonstrated that PAG may show distinctive roles among species. The review was aimed to analyze the activity of PAG in sheep by their spatiotemporal expression and their roles, further presenting alternatives to accelerate the understanding of pluripotency in this species.
\end{abstract}

Keywords: Ovis aries; totipotency; embryogenesis; embryology.

\section{Introdução}

A fecundação permite a singamia dos genomas dos gametas e inicia o desenvolvimento embrionário (Rossant, 2007, 2016; Moura, 2012). O recém-formado embrião passa por rápidas divisões celulares, período o qual as células do embrião são totipotentes, ou seja, possuem a capacidade de formar os os diversos tecidos do feto e da placenta (Smith, 2001; Rossant, 2007). O embrião passa pelo primeiro processo de diferenciação celular após a ativação do genoma embrionário, quando as células mais externas do embrião adquirem formato achatado, comum às células epiteliais (Rossant, 2007, 2016). No entanto, esta diferença morfológica persiste até o estádio de mórula (Rossant, 2007; Moura, 2012).

Os embriões no estádio de blastocisto apresentam dois tipos celulares distintos: embrioblastos e trofoblastos (Rossant, 2007). As células do embrioblasto são pluripotentes, pois tem a capacidade de se diferenciar nos tecidos que formam o feto (Smith, 2001; Rossant, 2016). As células do trofoblasto são as mais externas do blastocisto e possuem a capacidade de formar os 
tecidos que compõe a placenta (Rossant, 2007; Moura, 2012).

O cultivo do embrioblasto sob condições definidas permite $\mathrm{o}$ isolamento de linhagens celulares pluripotentes, com capacidade ilimitada de proliferação em roedores e primatas (Smith, 2001; Moura, 2012). Essas células pluripotentes em cultivo são denominadas de células-tronco embrionárias (CTEs). A estratégia definitiva para confirmar a pluripotência das CTEs é realizada pela introdução das CTEs em embriões de camundongos e ratos, resultando no nascimento de quimeras, ou seja, animais com contribuição das duas linhagens celulares em diversos tecidos, incluindo as gônadas (Bradley et al., 1984; Buehr et al., 2008; Li et al., 2008).

A pluripotência é regulada por diversos fatores, como fatores de transcrição, microRNAs, fatores epigenéticos, entre outros (Young, 2011; Moura, 2012; Yeo e Ng, 2013). Os genes relacionados à pluripotência (GRPs) contribuem para o estabelecimento e manutenção da pluripotência pelo controle do processo de diferenciação celular e manutenção da viabilidade de células pluripotentes. Cerca de cinquenta GRPs foram identificados e vários são necessários para manutenção da pluripotência (Avilion et al., 2003; Chambers et al., 2003; Mitsui et al., 2003; Bortvin et al., 2004; Galan-Caridad et al., 2007; Djosez et al., 2008; Masui et al., 2008; Zwaka, 2008; Moura, 2012; Silva et al., 2017).

A pluripotência pode ser estabelecida em células somáticas por diferentes métodos (Moura, 2012; Wu e Schöler, 2014). A introdução de uma célula somática em ovócito enucleado através da transferência nuclear (TN) permite a reativação dos GRPs no genoma da célula somática durante o desenvolvimento embrionário (Wilmut et al. 1997; Moura, 2012). Os embriões obtidos por TN resultam na produção de animais clones (Wilmut et al. 1997, 2002), sendo esta a maior evidência do reestabelecimento da pluripotência pela técnica (Moura, 2012; Wu e Schöler, 2014).

Uma demonstração mais direta da importância dos GRPs para o estabelecimento e manutenção da pluripotência foi obtida a partir da conversão de células somáticas em células pluripotentes por fatores definidos (Takahashi e Yamanaka, 2006; Takahashi et al., 2007; Wu e Schöler, 2014).

A expressão exógena de quatro GRPs (OCT4, SOX2, CMYC e KLF4) em células somáticas resultou em células pluripotentes equivalentes às CTEs em humanos $\mathrm{e}$ camundongos, denominadas de células pluripotentes induzidas (CPIs) (Takahashi e Yamanaka, 2006; Takahashi et al., 2007).

$\mathrm{O}$ rápido progresso no entendimento do controle da pluripotência deve-se em grande parte, a utilização de CTEs, CPIs e métodos que permitem a investigação funcional e em nível genômico dos GRPs em camundongos e humanos (Capecchi, 1989; Boyer et al., 2005; Wang et al., 2006). No entanto, tais ferramentas permanecem indisponíveis ou pouco utilizadas em ovinos (Williams et al., 2003). Além disso, as tentativas de estabelecer CTEs e CPIs em ovinos ainda não foram eficientes (Bao et al., 2011; Shi et al., 2015), devido ao limitado conhecimento sobre a pluripotência na espécie (Ezashi et al., 2016). Por estes fatos, o controle da pluripotência em ovinos permanece pouco explorado.

Evidências em bovinos demonstram que a expressão espaço-temporal e regulação de GRPs em embriões difere das descritas em camundongos e humanos (Berg et al., 2011; Rossant, 2011; Goissis e Cibelli, 2014). Além disso, diversos relatos apresentam particularidades espécieespecíficas na atividade de GRPs em CTEs (Boyer et al., 2005; Loh et al., 2006; Au e Sebastiano, 2014). Estes fatos suportam a necessidade de investigar o controle da pluripotência em diferentes organismos. O objetivo foi revisar a atividade dos GRPs em ovinos através do perfil de expressão espaço-temporal e funções, bem como apresentar alternativas para acelerar o entendimento da pluripotência na espécie.

\section{Revisão Bibliográfica}

A revisão foi realizada através de buscas nos bancos de indexação PUBMED - medline (www.pubmed.org) e Science Direct (www.sciencedirect.com). A busca por artigos utilizou os termos de busca (Keywords) "ovine", "Ovis aries" ou "sheep", nas diferentes combinações possíveis com os seguintes genes, OCT4 (POU5F1), NANOG, STAT3, SOX2, KLF4, KLF5, SALL2, SALL4, TBX3, RONIN (THAP11), ZFP281, NAC1 (NACC1), DAX1 (NR0B1), TLC1A, LIN28, GDF3, TCF3, GLIS1, REX1 (ZFP42), FOXD3, UTF1, DPPA1, DPPA2, DPPA3 (STELLA/PGC7), DPPA4, DPPA5, CMYC, LRH-1 (NR5A2), ESRR $\beta$ e ZFX. Apenas os artigos contendo informações sobre a expressão espaço-temporal e funções dos GRPs em ovinos 
foram considerados. Evitou-se a citação de vários artigos com informações semelhantes.

\section{Expressão espaço-temporal dos genes relacionados à pluripotência em ovinos}

A expressão espaço-temporal de GRPs em ovinos tem sido melhor caracterizada durante o desenvolvimento embrionário, pois 13 genes foram detectados em gametas ou algum estádio de desenvolvimento. Além disso, GRPs foram detectados em células germinativas primordiais e células pluripotentes de ovinos (Figura 1). Ao considerar o número de GRPs caracterizados em camundongos e humanos, poucos genes foram analisados em ovinos até o momento.

Os genes apresentam alguns padrões de expressão temporal durante o desenvolvimento embrionário (Bortvin et al., 2004; Rossant, 2007), incluindo os GRPs. O padrão de expressão materno caracteriza-se pelo RNA mensageiro (RNAm) estocado no gameta feminino, que persiste nas primeiras clivagens, embora não seja detectado após a ativação do genoma embrionário (Hosseini et al., 2016). Em contrapartida, alguns genes são expressos após a ativação do genoma embrionário, a partir do estádio de oito para dezesseis células. Outros GRPs são expressos durante todo o desenvolvimento embrionário (Bernardi et al., 1996; Sanna et al., 2010; Silva et al., 2017).

O GRPs melhor caracterizado em ovinos é octamer-binding transcription factor 4 (OCT4), também denominado como POU5F1 (Zeineddine et al., 2014). Este gene foi detectado no embrioblasto, trofoblasto e cultivos de embrioblasto (Sanna et al., 2010; Kim et al., 2013; Wang et al., 2013a). Células somáticas não expressam OCT4, confirmando expressão restrita às células pluripotentes, enquanto que 0 embrioblasto apresentou maiores níveis de expressão que o trofoblasto (Sanna et al., 2010). Esses resultados sugerem que OCT4 possa controlar o processo diferenciação do embrião em ovinos (Sanna et al., 2010). Este gene também foi detectado no concepto até o dia 21 de gestação de ovinos e sua expressão foi inversamente proporcional a do interferon-tau, que contribui para o reconhecimento materno da gestação (Kim et al., 2013).
NANOG, OCT4, REX1

STELLA, SOX2

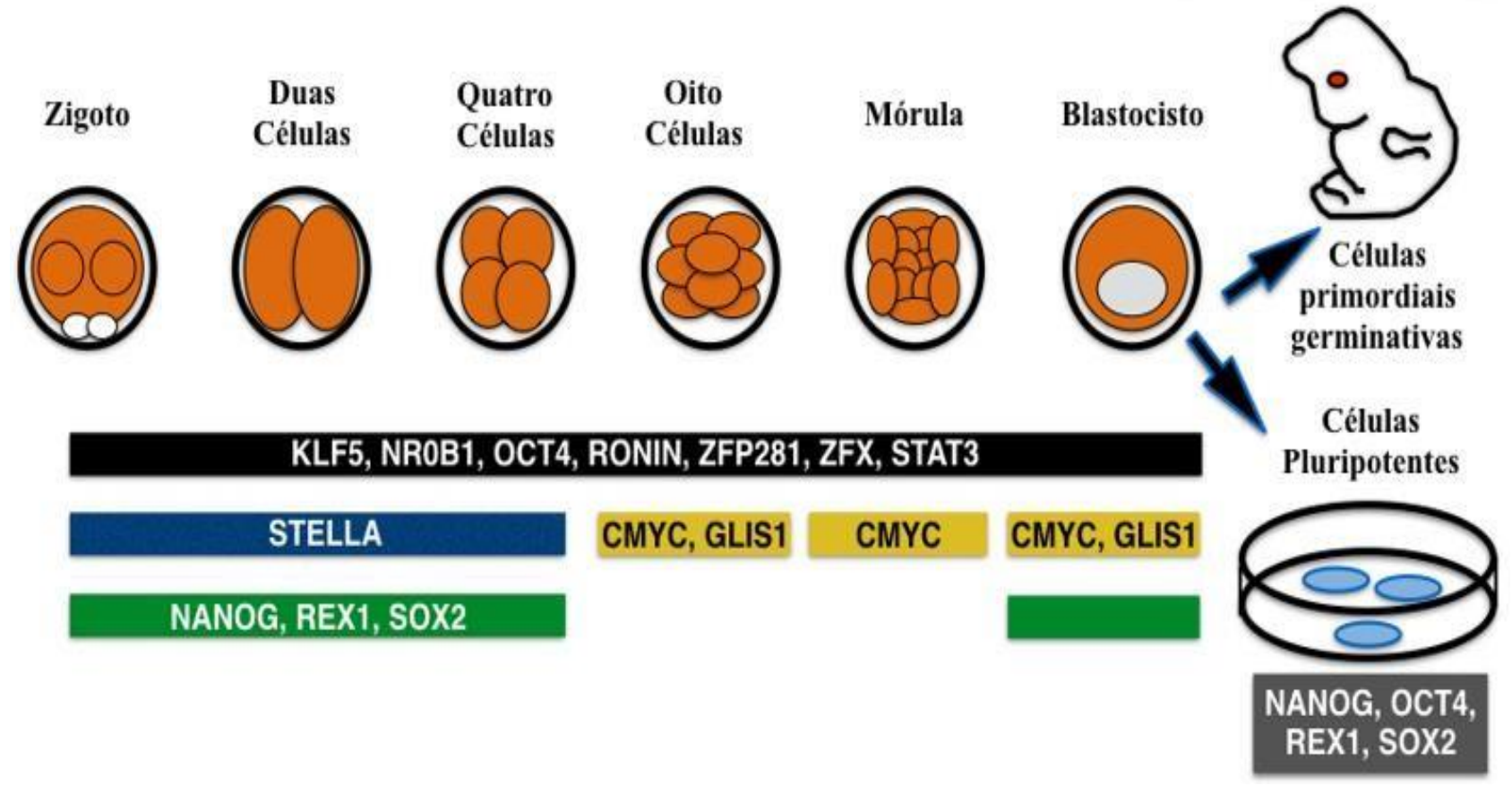

Figura 1. Expressão temporal dos genes relacionados à pluripotência em embriões, células germinativas primordiais germinativas e células pluripotentes de ovinos. Células pluripotentes: cultivos de embrioblasto ou células pluripotentes induzidas (CPIs). Preto: Bernardi et al., 1996; Ma et al., 2014; Shirazi et al., 2015; Miao et al., 2016; Silva et al., 2017. Azul: Hosseini et al., 2016. Amarelo: Silva et al., 2017. Verde: Ma et al., 2014; Hosseini et al., 2016. Roxo: Payen et al., 1997; Liu et al., 2014; Parte et al., 2014. Cinza: Bao et al., 2011; Shi et al., 2015; Su et al., 2015. 


\section{Funções dos genes relacionados à pluripotência em ovinos}

O gene OCT4 foi o primeiro GRPs caracterizado em mamíferos (Schöler et al., 1989; Rosner et al., 1990). Além disso, OCT4 permanece como o principal GRPs estudado e o único indispensável para manutenção da pluripotência em camundongos e humanos (Nichols et al., 1998; Wu e Schöler, 2014; Zeineddine et al., 2014). As avaliações em ovinos demonstraram que OCT4 pode ser utilizado como marcador de células pluripotentes (Tabela 1), pois sua expressão está restrita à estas células (Sanna et al., 2010). A expressão de OCT4 também está correlacionada com a viabilidade de gametas e embriões que apresentam maior potencial de desenvolvimento em ovinos (Wang et al., 2013a). A expressão inversamente proporcional entre OCT4 e o interferon-tau sugere que o GRPs participe do controle do reconhecimento materno da gestação em ovinos (Kim et al., 2013), embora este mecanismo precisa ser demonstrado experimentalmente.

O gene OCT4 permanece como único GRPs com inferências sobre função na pluripotência em ovinos, conforme descrito acima (Sanna et al., 2010; Kim et al., 2013; Wang et al., 2013a). Entretanto, pelo nosso conhecimento, ainda não existem investigações sobre a função de GRPs em gametas, embriões e células pluripotentes de ovinos. Uma alternativa para inferir possíveis funções de GRPs em células pluripotentes de ovinos seria analisar a expressão e funções destes genes em células somáticas (Tabela 1).

NANOG foi identificado em camundongos como potencial GRPs por métodos in silico, por ter expressão restrita aos embriões e CTEs (Chambers et al., 2003; Matsui et al., 2003). Este perfil de expressão do NANOG também foi descrito em ovinos, enquanto que o fator de crescimento fibroblast growth factor 2 (FGF2) reduz sua expressão (Moradi et al., 2015). A expressão exógena de NANOG em células-tronco mesenquimais (CTM) de ovinos adulto rejuvenesceu estas células, recuperando a capacidade proliferativa e de diferenciação equivalente as CTM de ovinos neonatos (Han et al., 2012).

A família de genes SRY-related highmobility-group box (SOX) possui 20 membros, embora SOX2 seja o único considerado GRPs (Jauch et al., 2011). O gene SOX2 apresenta expressão nas células primordiais germinativas (CPG), embriões antes da implantação e no cérebro durante o período fetal (Payen et a., 1997). Além disso, este gene mostrou-se necessário para manutenção da pluripotência em camundongos e bovinos (Avilion et al., 2003; Goissis e Cibelli, 2014). SOX2 foi caracterizado em ovinos (Tabela 1), apresentando alto grau de conservação em nível de RNAm e proteína (Payen et al., 1995, 1997; Brus et al., 2012). Este fato sugere que as funções descritas em células pluripotentes de camundongos e bovinos possam ser conservadas em ovinos. Análises in silico e funcionais referentes aos domínios de NANOG e SOX2 poderão contribuir para avaliar possíveis funções destes GRPs em ovinos. Estas abordagens podem também auxiliar as investigações sobre os genes ZFX e STAT3, que não apresentam descrições sobre suas funções em ovinos.

O gene C-MYC é um dos proto-oncogenes melhor caracterizados em mamíferos, sendo expresso em diversos tecidos somáticos, embriões e CTEs de camundongos e humanos (Scognamiglio et al., 2016). Este gene é capaz de imortalizar cultivos celulares primários de ovinos (Kiemer et al., 1997; Scognamiglio et al., 2016), confirmando seu potencial oncogênico na espécie. A sequência do C-MYC ovino foi caraterizada em nível de RNAm e proteína a partir de uma linhagem celular imortalizada (Kiemer et al., 1997). O C-MYC ovino apresenta homologia acima de $92 \%$, na comparação entre a sequência proteica de ovinos e outros mamíferos (Kiemer et al., 1997).

Os cinco genes (DPPA) fazem parte de uma família que atua como proteínas associadas à cromatina (Peirre et al., 2005). Os genes DPPAs são expressos em CPGs e embriões de camundongos e humanos (Payer et al., 2003; Kim et al., 2005), enquanto que DPPA3 demonstrou ser marcador de pluripotência em camundongos (Bowles et al., 2003; Bortvin et al 2004). Um estudo em ovinos identificou polimorfismos nos genes DPPA2 e DPPA4 que foram associados com maior predisposição a infeção pelo lentivírus ovino (White et al., 2012). A reprogramação celular por fatores definidos em ovinos utilizando células somáticas de animais com polimorfismos nos DPPAs poderia determinar se existe variação na eficiência de transdução com lentivírus nestes indivíduos. Este fato, por sua vez, permitiria correlacionar o genótipo do animal com a eficiência da reprogramação celular. 
Tabela 1. Localização, funções e aplicações de genes relacionados à pluripotência em células somáticas de ovinos (Ovis aries).

\begin{tabular}{|c|c|c|c|c|}
\hline Gene & Descrição & Localização & Funções ou aplicações & Autor \\
\hline CMYC & $\begin{array}{l}\text { Fator de } \\
\text { transcrição }\end{array}$ & $\begin{array}{c}\text { Células imortalizadas e } \\
\text { adipócitos }\end{array}$ & $\begin{array}{c}\text { Proteína com alta conservação em } \\
\text { mamíferos }\end{array}$ & $\begin{array}{l}\text { Kiemer et al., } 1997 \\
\text { Basse et al., } 2015\end{array}$ \\
\hline $\begin{array}{c}\text { DAX1 } \\
\text { (NR0B1) }\end{array}$ & $\begin{array}{l}\text { Fator de } \\
\text { transcriçãa }\end{array}$ & Granulosa & $\begin{array}{c}\text { Polimorfismo associado à } \\
\text { prolificidade }\end{array}$ & Miao et al., 2016 \\
\hline $\begin{array}{l}\text { DPPA2, } \\
\text { DPPA4 }\end{array}$ & $\begin{array}{l}\text { Fator de } \\
\text { transcrição }\end{array}$ & - & $\begin{array}{l}\text { Polimorfismo associado à } \\
\text { susceptibilidade de infecção de } \\
\text { lentivírus }\end{array}$ & White et al., 2012 \\
\hline KLF4 & $\begin{array}{l}\text { Fator de } \\
\text { transcrição }\end{array}$ & $\begin{array}{l}\text { Epiderme, granulosa e } \\
\text { adipócitos }\end{array}$ & $\begin{array}{l}\text { Atividade está associada ao } \\
\text { escurecimento da pele e lã }\end{array}$ & $\begin{array}{l}\text { Natesanpillai et al., } 2008 \\
\text { Peñagaricano et al., } 2012 \\
\text { Basse et al., } 2015\end{array}$ \\
\hline $\begin{array}{c}\text { LRH1 } \\
\text { (NR5A2) }\end{array}$ & $\begin{array}{l}\text { Receptor } \\
\text { nuclear }\end{array}$ & $\begin{array}{l}\text { Fígado, hipófise, } \\
\text { hipotálamo, ovário e } \\
\text { oviduto }\end{array}$ & $\begin{array}{l}\text { Polimorfismo associado à } \\
\text { prolificidade }\end{array}$ & $\begin{array}{l}\text { Wang et al., } 2013^{\mathrm{b}} \\
\text { Li et al., } 2015\end{array}$ \\
\hline NANOG & $\begin{array}{l}\text { Fator de } \\
\text { transcrição }\end{array}$ & $\begin{array}{l}\text { Embriões e cultivo de } \\
\text { embrioblasto }\end{array}$ & $\begin{array}{l}\text { Rejuvenesce células da medula } \\
\text { óssea; FGF reduz sua expressão }\end{array}$ & $\begin{array}{l}\text { Han et al., 2012; } \\
\text { Moradi et al., } 2015\end{array}$ \\
\hline $\begin{array}{c}\text { OCT4 } \\
\text { (POU5F1) }\end{array}$ & $\begin{array}{l}\text { Fator de } \\
\text { transcrição }\end{array}$ & Concepto & $\begin{array}{l}\text { Inibe o interferon-Tau; } \\
\text { marcador de viabilidade } \\
\text { embrionária }\end{array}$ & $\begin{array}{l}\text { Sanna et al., } 2010 \\
\text { Kim et al., 2013; } \\
\text { Wang et al., 2013 }\end{array}$ \\
\hline SOX2 & $\begin{array}{l}\text { Fator de } \\
\text { transcrição }\end{array}$ & Cérebro e gônadas fetais & $\begin{array}{l}\text { Possível controle da } \\
\text { neoneurogênese; Proteína com } \\
\text { alta conservação em mamíferos }\end{array}$ & $\begin{array}{l}\text { Payen et al., } 1995 \\
\text { Payen et al., } 1997 \\
\text { Brus et al., } 2012\end{array}$ \\
\hline STAT3 & $\begin{array}{l}\text { Fator de } \\
\text { transcrição }\end{array}$ & $\begin{array}{l}\text { Concepto, útero, } \\
\text { glândula mamária e } \\
\text { coração }\end{array}$ & $\begin{array}{l}\text { Expressão associada a } \\
\text { criotolerância de embriões }\end{array}$ & $\begin{array}{c}\text { Dong et al., } 2008 \\
\text { Colitti e Farinacci, } 2009 \\
\text { Song et al., } 2009 \\
\text { Shirazi et al., } 2015\end{array}$ \\
\hline ZFX & $\begin{array}{l}\text { Fator de } \\
\text { transcricão }\end{array}$ & Tecido muscular & $\begin{array}{l}\text { Sequência utilizada para sexagem } \\
\text { de embriões }\end{array}$ & Bernardi et al., 1996 \\
\hline
\end{tabular}

Os receptores nucleares NR5A2 e NR0B1 são importantes para diversos processos biológicos durante a embriogênese de mamíferos (Wang et al., 2013b; Miao et al., 2016). Em células pluripotentes, NR5A2 é expresso em gametas, embriões e CTEs, além de substituir OCT4 na reprogramação celular por fatores definidos em camundongos (Heng et al., 2010). Em ovinos, NR5A2 foi detectado em nível de RNAm e proteína na hipófise, hipotálamo, ovários e ovidutos (Wang et al., 2013b). As células da granulosa de ovinos expressam NR5A2 (Wang et al., 2013b) e NR0B1 (Miao et al., 2016), fato que sugere que este tipo celular seja uma possível alternativa para investigações sobre a função destes genes durante a reprogramação celular em ovinos.

O gene Kruppel-like Factor 4 (KLF4) é um fator de transcrição com expressão em diversos tecidos somáticos (Farrugia et al., 2016). Em ovinos, KLF4 foi identificado a partir de uma prospeção de genes correlacionados ao escurecimento da pele e lã na raça corridale (peñagaricano et al., 2012). A expressão do gene é alta em melanócitos, enquanto que a exposição à ultravioleta aumenta sua atividade (Peñagaricano et al., 2012; Farrugia et al., 2016). A comparação entre melanócitos e fibroblastos para reprogramação celular por fatores definidos em ovinos seria uma alternativa para prospectar genes envolvidos no processo de estabelecimento da pluripotência na espécie.

\section{Alternativas para investigação dos GRPs em ovinos}

A expressão de GRPs em células de ovinos tem sido analisada pela reação em cadeia da polimerase (PCR) convencional ou RT-PCR quantitativa em tempo real (Bernardi et al., 1996; Sanna et al., 2010; Silva et al., 2017). No entanto, estas técnicas são laboriosas, avaliam poucos genes simultaneamente e não permitem avaliar variações entre células ou blastômeros nos diferentes estádios do desenvolvimento embrionário. A utilização de métodos de avaliação da expressão gênica em células individuais (Boiani e Cibelli, 2016) ou de todo o transcriptoma (Au e Sebastiano, 2014) deverão auxiliar na caracterização dos GRPs em ovinos. 
As CTEs se tornaram uma alternativa para investigar a pluripotência pela capacidade de autorenovação (self-renewal) e facilidade para alteração do seu genoma (Capecchi, 1989). Ao contrário de gametas e embriões, as CTEs podem ser facilmente propagadas para obtenção de material biológico suficiente para investigações sobre a pluripotência em nível genômico (Boyer et al., 2005; Loh et al., 2006). No entanto, CTEs ainda não foram estabelecidas em ovinos e outros animais de produção (Ezashi et al., 2016). A utilização da reprogramação celular para obtenção de CPIs em ovinos demonstrou que estas células expressam GRPs e apresentam capacidade de diferenciação in vitro e in vivo (Bao et al., 2011; Sartori et al., 2012; Ogorevc et al., 2016). No entanto, as CTEs e CPIs de ovinos ainda não demonstraram capacidade de formar gametas in vivo (Sartori et al., 2012; SHI et al., 2015), portanto não podem ser consideradas pluripotentes (Smith, 2001; Ezashi et al., 2016). A identificação das vias de sinalização que permitem a auto-renovação de CTEs e CPIs de ovinos deverá contribuir para o estabelecimento de linhagens pluripotentes na espécie (Ezashi et al., 2016).

A investigação da função gênica surgiu com o desenvolvimento do sistema de mutagênese por recombinação homóloga $(\mathrm{RH})$ em CTEs de camundongos (Capecchi, 1989, 2005). No entanto, devido a indisponibilidade de CTEs de ovinos, as tentativas de $\mathrm{RH}$ em células somáticas apresentaram importantes limitações, como a limitada capacidade proliferativa e menor eficiência de recombinação (Mccreath et al., 2000; Williams et al., 2003). Apesar disso, as células somáticas submetidas à $\mathrm{RH}$ podem ser utilizadas para obtenção de ovinos mutantes a partir da clonagem por TN (Mccreath et al., 2000).

Novas metodologias tornaram a edição do genoma mais precisa e eficiente (Petersen e Niemann, 2015). Entre eles, o sistema CRISPRCAS9 é eficiente para editar genes em embriões ovinos (Crispo et al., 2015; Wang et al., 2016) e poderá contribuir para identificação dos GRPs necessários para viabilidade de células pluripotentes e desenvolvimento embrionário de ovinos. Os GRPs identificados neste processo poderão ser melhor caracterizados quanto aos mecanismos que contribuem para o controle da pluripotência em ovinos.

\section{Considerações Finais}

As descrições sobre GRPs em ovinos permanecem limitadas a determinação da expressão espaço-temporal de poucos genes e algumas funções em células somáticas. Investigações funcionais permitirão identificar GRPs necessários para pluripotência em ovinos. Além disso, a elucidação dos mecanismos de controle da pluripotência deverá contribuir para o desenvolvimento das tecnologias de reprogramação celular e obtenção de células pluripotentes na espécie.

\section{Referências}

Au, K.F.; Sebastiano, V. The transcriptome of human pluripotent stem cells. Current Opinion in Genetics and Development, 28: 71-77, 2014.

Avilion, A.A.; Nicolis, S.K.; Pevny, L.H.; Perez, L.; Vivian, N.; Lovell-Badge, R. Multipotent cell lineages in early mouse development depend on SOX2 function. Genes and Development, 17: 126-140, 2003.

Bao, L.; He, L.; Chen, J.; Wu, Z.; Liao, J.; Rao, L.; Ren, J.; Li, H.; Zhu, H.; Qian, L.; Gu, Y.; Dai, H.; Xu, X.; Zhou, J.; Wang, W.; Cui, C.; Xiao L. Reprogramming of ovine adult fibroblasts to pluripotency via druginducible expression of defined factors. Cell Research, 21: 600- 608, 2011.

Basse, A.L.; Dixen, K.; Yadav, R.; Tygesen, M.P.; Qvortrup, K.; Kristiansen, K.; Quistorff, B.; Gupta, R.; Wang, J.; Hansen, J.B. Global gene expression profiling of brown to white adipose tissue transformation in sheep reveals novel transcriptional components linked to adipose remodeling. BMC Genomics, 19(215): 2015.

Berg, D.K.; Smith, C.S.; Pearton, D.J.; Wells, D.N.; Broadhurst, R.; Donnison M.; Pfeffer, P.L. Trophectoderm lineage determination in cattle. Developmental Cell, 20: 244-255, 2011.

Bernardi, M.L; Cotinot, C.; Payen, E.; Delouis, C. Transcription of $\mathrm{Y}$ - and $\mathrm{X}$-Linked Genes in Preimplantation Ovine Embryos. Molecular Reproduction and Development, 45: 132138, 1996.

Boiani, M.; Cibelli, J.B. What we can learn from single-cell analysis in development. Molecular Human Reproduction, 22: 160-171, 2016. 
Bortvin, A.; Goodheart, M.; Liao, M.; Page, D.C. Dppa3 / Pgc7 / stella is a maternal factor and is not required for germ cell specification in mice. BMC Developmental Biology, 4: 15,2004

Bowles, J.; Teasdale, R.P.; James, K.; Koopman, P. Dppa3 is a marker of pluripotency and has a human homologue that is expressed in germ cell tumours. Cytogenetic and Genome Research, 101:261-265, 2003.

Boyer, L.A.; Plath, K.; Zeitlinger, J.; Brambrink, T.; Medeiros, L.A.; Lee, T.I.; Levine, S.S.; Wernig, M.; Tajonar, A.; Ray, M.K.; Bell, G.W.; Otte, A.P.; Vidal, M.; Gifford, D.K.; Young, R.A.; Jaenisch, R. Core transcriptional regulatory circuitry in human embryonic stem cells. Cell, 122: 947-956, 2005.

Bradley, A.; Evans M.; Kaufman, M.H; Robertson, E. Formation of germ-line chimaeras from embryo-derived teratocarcinoma cell lines. Nature, 309: 255-256, 1984.

Brus, M.; Meurisse, M.; Gheusi, G.; Keller, M.; Lledo, P.M.; Lévy, F. Dynamics of olfactory and hippocampal neurogenesis in adult sheep. Journal of Comparative Neurology, 521: 169-188, 2013.

Buehr, M.; Meek, S.; Blair, K.; Yang, J.; Ure, J.; Silva, J.; Mclay, R.; Hall, J.; Ying, Q.L.; Smith, A. Capture of authentic embryonic stem cells from rat blastocysts. Cell, 135: 1287-1298, 2008.

Capecchi, M.R. Altering the genome by homologous recombination. Science, 244: 1288-1292, 1989.

Capecchi, M.R. Gene targeting in mice: functional analysis of the mammalian genome for the twenty-first century. Nature Reviews Genetics, 6: 507-512, 2005.

Chambers, I.; Colby, D.; Robertson, M.; Nichols, J.; Lee, S.; Tweedie, S.; Smith, A. Functional expression cloning of Nanog, a pluripotency sustaining factor in embryonic stem cells. Cell, 113: 643-655, 2003.

Colitti, M.; Farinacci, M. Cell turnover and gene activities in sheep mammary glands prior to lambing to involution. Tissue and Cell, 41: 326-333, 2012.

Crispo, M.; Mulet, A.P.; Tesson, L.; Barrera, N.; Cuadro, F.; dos Santos-Neto, P.C.; Nguyen, T.H.; Crénéguy, A.; Brusselle, L.; Anegón, I.; Menchaca, A. Efficient Generation of Myostatin Knock-Out Sheep Using
CRISPR/Cas9 Technology and croinjection into Zygotes. PLoS One, 10(e0136690): 2015.

Djosez, M.; Krumenacker, J.S.; Zitur, L.J.; Passeri, M.; Chu, L.F.; Songyang, Z.; Thomson, J.A.; Zwaka, T.P. Ronin is essential for embryogenesis and the pluripotency of mouse embryonic stem cells. Cell, 133: 1162-1174, 2008.

Dong, F.; Ford, S.P.; Nijland, M.J.; Nathanielsz, P.W.; Ren, J. Influence of maternal undernutrition and overfeeding on cardiac ciliary neurotrophic factor receptor and ventricular size in fetal sheep. Journal of Nutritional Biochemestry, 19: 409-414, 2008.

Ezashi, T.; Yuan, Y.; Roberts, R.M. Pluripotent Stem Cells from Domesticated Mammals. Annual Review of Animal Biosciences, 4: 223-253, 2016.

Farrugia, M.K.; Vanderbilt, D.B.; Salkeni, M.A.; Ruppert, J.M. Kruppel-like Pluripotency Factors as Modulators of Cancer Cell Therapeutic Responses. Cancer Research, 76: 1677-1682, 2016.

Galan-Caridad, J.M.; Harel, S.; Arenzana, T.L.; Hou, Z.E.; Doestsch, F.K.; Mirny, L.A.; Reizis, B. Zfx controls the self-renewal of embryonic and hematopoietic stem cells. Cell, 129: 345-357, 2007.

Goissis, M.D.; Cibelli, J.B. Functional characterization of SOX2 in bovine preimplantation embryos. Biology of Reproduction, 90(30): 2014.

Han, J.; Mistriotis, P.; Lei, P.; Wang, D.; Liu, S.; Androids, S.T. Nanog reverses the effects of organismal aging on mesenchymal stem cell proliferation and myogenic differentiation potential. Stem Cells, 30: 2746-2759, 2012.

Heng, J.C.; Feng, B.; Han, J.; Jiang, J.; Kraus, P.; Ng, J.H.; Orlov, Y.L.; Huss, M.; Yang, L.; Lufkin, T.; Lim, B.; Ng, H.H. The nuclear receptor Nr5a2 can replace Oct4 in the reprogramming of murine somatic cells to pluripotent cells. Cell Stem Cell, 6: 167174, 2010.

Hosseini, S.M.; Moulavi, F.; Tanhaie-Vash, N.; Asgari, V.; Ghanaei, H.R.; Abedi-Dorche, M.; Jafarzadeh, N.; Gourabi, H.; Shahverdi, A.H.; Dizaj, A.V.; Shirazi, A.; NasrEsfahani, M.H. The Principal Forces of Oocyte Polarity Are Evolutionary Conserved but May Not Affect the 
Contribution of the First Two Blastomeres to the Blastocyst Development in Mammals. PLoS One, 11(e0148382): 2016.

Jauch, R.; Aksoy, I.; Hutchins, A.P.; Ng, C.K.; Tian, X.F.; Chen, J.; Palasingam, P.; Robson, P.; Stanton, L.W.; Kolatkar, P.R. Conversion of Sox17 into a pluripotency reprogramming factor by reengineering its association with Oct4 on DNA. Stem Cells, 29: 940-951, 2011.

Kiemer, V.; Dequiedt, F.; Masengo, R.; Cleuter, Y.; Briclet,D.; Ciesiolka, M.; Broeke, A.V.D.; Willems, L.; Kettmann, R.; Burny, A.; Droogmans, L. The Cloning Sequencing of an Ovine c-Myc cDNA. DNA sequence: The Journal of DNA Sequencing and Mapping, 7: 235-238, 1997.

Kim, M.S.; Sakurai, T.; Bai, H.; Bai, R.; Sato, D.; Nagaoka, K.; Chang, K.T.; Godkin, J.D.; Min, K.S.; Imakawa, K. Presence of Transcription Factor OCT4 limits Interferon-tau Expression during the Preattachment Period in Sheep. Asian Australasian Journal of Animal Science, 26: 638-645, 2013.

Li, P.; Tong, C.; Mehrian-Shai, R.; Jia, L.; Wu, N.; Yan, Y.; Maxson, R.E.; Schulze, E.N.; Song, H.; Hsieh, C.L.; Pera, M.F.; Ying, Q.L. Germline competent embryonic stem cells derived from rat blastocysts. Cell, 135: 1299- 1310, 2008.

Li, Y.X.; Zhang, J.; Qian, Y.; Meng, C.H.;Wang, H.L.; Tao, X.J.; Zhong, S.; Cao, S.X.; Li, Q.F. Molecular characterization, expression, polymorphism of NR5A2 and its relationship with litter size in $\mathrm{Hu}$ sheep. Genetics and Molecular Research, 14: 12765-12775, 2015.

Liu, C.X.; Wang, W.L.; Zhao, R.Y.; Wang, H.T.; Liu, Y.Y.; Wang, S.Y.; Zhou, H.M. Isolation, culture, and characterization of primordial germ cells in Mongolian sheep. In Vitro Cellular \& Developmental Biology - Animal, 50: 207-213, 2014.

Loh, Y.H.; Wu, Q.; Chew, J.L.; Vega, V.B.; Zhang, W.; Chen, X.; Bourque, G.; George, J.; Leong, B.; Liu, J.; Wong, K.Y.; Sung, K.W.; Lee, C.W.; Zhao, X.D.; Chiu, K.P.; Lipovich, L.; Kuznetsov, V.A.; Robson, P.; Stanton, L.W.; Wei, C.L.; Ruan, Y.; Lim, B.; Ng, H.H. The Oct4 and Nanog transcription network regulates pluripotency in mouse embryonic stem cells. Nature Genetics, 38: 431-440, 2006.

Ma, L.B.; He, X.Y.; Wang, F.M.; Cao, J.W.; Cheng, $\mathrm{T}$. The development and expression of pluripotency genes in embryos derived from nuclear transfer and in vitro fertilization. Zygote, 22: 540-548, 2014.

Masui, S.; Ohtsuka, S.; Yagi, R.; Takahashi, K.; Ko, M.S.; Niwa, H. Rex1/Zfp42 is dispensable for pluripotency in mouse ES cells. BMC Developmental Biology, 8: 112, 2008.

McCreath, K.J.; Howcroft, J.; Campbell, K.H.; Colman, A.; Schnieke, A.E.; Kind, A.J. Production of gene-targeted sheep by nuclear transfer from cultured somatic cells. Nature, 405: 1066-1069, 2000.

Miao, X.; Luo, Q.; Zhao, H.; Qin, X. Co-expression analysis and identification of fecundityrelated long non-coding RNAs in sheep ovaries. Science Reports, 16(39398): 2016.

Mitsui, K.; Tokuzawa, Y.; Itoh, H.; Segawa, K.; Murakami, M.; Takahashi, K.; Maruyama, M.; Maeda, M.; Yamanaka, S. The homeoprotein Nanog is required for maintenance of pluripotency in mouse epiblast and ES cells. Cell, 113: 631-642, 2003.

Moradi, M.; Riasi, A.; Ostadhosseini, S.; Hajian, M.; Hosseini, M.; Hosseinnia, P.; NasrEsfahani, M.H. Expression profile of FGF receptors in preimplantation ovine embryos and the effect of FGF2 and PD173074. Growth Factors, 33: 393-400, 2015.

Moura, M.T. Pluripotency and cellular reprogramming. Anais da Academia Pernambucana de Ciência Agronômica, 8: 138-168, 2012.

Natesampillai, S.; Kerkvliet, J.; Leung, P.C.; Veldhuis, J.D. Regulation of Kruppel-like factor 4, 9, and 13 genes and the steroidogenic genes LDLR, StAR, and CYP11A in ovarian granulosa cells. American Journal Physiology Endocrinology Metabolism, 294: e385e391, 2008.

Nichols, J.; Zevnik, B.; Anastassiadis, K.; Niwa, H.; Klewe-Nebenius, D.; Chambers, J.; Schöler, H.; Smith, A. Formation of pluripotent stem cells in the mammalian embryo depends on the POU transcription factor Oct4. Cell, 95: 379-391, 1998. 
Ogorevc, J.; Orehek, S.; Dovč, P. Cellular reprogramming in farm animals: an overview of iPSC generation in the mammalian farm animal species. Journal of Animal Science and Biotechnology, 7(10): 2016.

Parte, S.; Bhartiya, D.; Patel, H.; Daithankar, V.; Shaun, A.; Zaveri, K.; Hinduja, I. Dynamics associated with spontaneous differentiation of ovarian stem cells in vitro. Journal of Ovarian Research, 25(25): 2014.

Payen, E.; Saidi-Mehtar, N.; Pailhoux, E.; Cotinot, C. Sheep gene mapping: assignment of ALDOB, GYPW, VVT and SOX2 by somatic cell hybrid analysis. Animal Genetics, 26: 331-333, 1995.

Payen, E.; Pailhoux, E.; Gianquinto, L.; Hayes, H.; Le Pennec, N.; Bezard, J.; Cotinot, C. The ovine SOX2 gene: sequence, chromosomal localization and gonadal expression. Gene and International Journal on Genes and Genomes, 189: 143-147, 1997.

Payer, B.; Saitou, M.; Barton, S.C.; Thresher, R.; Dixon, J.P.; Zahn, D.; Colledge, W.H.; Carlton, M.B.; Nakano, T.; Surani, M.A. Stella is a maternal effect gene required for normal early development in mice. Current Biology, 13: 2110-2117, 2003.

Peñagaricano, F.; Zorrilla, P.; Naya, H.; Robello, C.; Urioste, J.I. Gene expression analysis identifies new candidate genes associated with the development of black skin spots in Corriedale sheep. Journal of Applied Genetics, 53: 99-106, 2012.

Petersen, B.; Niemann, H. Molecular scissors and their application in genetically modified farm animals. Transgenic Research, 24: 381-396, 2015.

Pierre, A.; Gautier, M.; Callebaut, I.; Bontoux, M.; Jeanpierre, E.; Pontarotti, P.; Monget, P. Atypical structure and phylogenomic evolution of the new eutherian oocyte- and embryo-expressed DC1/DPPA5/ECAT1/OOEP gene family. Genomics, 90: 583-594, 2007.

Rosner, M.H.; Vigano, M.A.; Ozato, K.; Timmons, P.M.; Poirier, F.; Rigby, P.W.; Staudt, L.M. A POU-domain transcription factor in early stem cells and germ cells of the mammalian embryo. Nature, 345: 686-692, 1990.
Rossant, J. Stem cells and lineage development in the mammalian blastocyst. Reproduction, Fertility and Development, 19: 111-118, 2007.

Rossant, J. Developmental biology: A mouse is not a cow. Nature, 471: 457-458, 2011.

Rossant, J. Making the Mouse Blastocyst: Past, Present, and Future. Current Topics in Developmental Biology, 117: 275-288, 2016. Salabi, F.; Nazari, M.; Cao, W.G. Cell culture, sex determination and single cell cloning of ovine transgenic satellite cells in vitro. Journal of Biological ResearchThessaloniki, 21(22): 2014.

Sanna, D.; Sanna, A.; Mara, L.; Pilichi, S.; Mastinu, A.; Chessa, F.; Pani, L.; Dattena, M. Oct4 expression in in-vitro-produced sheep blastocysts and embryonic-stem-like cells. Cell Biology International, 34: 5360, 2010.

Sartori, C.; DiDomenico, A.I.; Thomson, A.J.; Milne, E.; Lillico, S.G.; Burdon, T.G.; Whitelaw, C.B. Ovine-induced pluripotent stem cells can contribute to chimeric lambs. Cellular Reprogramming, 14: 8-19, 2012.

Schöler, H.R.; Hatzopoulos, A.K.; Balling, R.; Suzuki, N.; Gruss, P. A family of octamerspecific proteins present during mouse embryogenesis: evidence for germlinespecific expression of an Oct factor. EMBO Journal, 8: 2543-2550, 1989.

Scognamiglio, R.; Cabezas-Wallscheid, N.; Thier, M.C.; Altamura, S.; Reyes, A.; Prendergast, Á.M.; Baumgärtner, D.; Carnevalli, L.S.; Atzberger, A.; Haas, S.; Von Paleske, L.; Boroviak, T.; Wörsdörfer, P.; Essers, M.A.; Kloz, U.; Eisenman, R.N.; Edenhofer, F.; Bertone, P.; Huber, W.; Van Der Hoeven, F.; Smith, A.; Trumpp, A. Myc Depletion Induces a Pluripotent Dormant State Mimicking Diapause. Cell, 164: 668-680, 2016.

Shi, H.; Fu, Q.; Li, G.; Ren, Y.; Hu, S.; Ni, W.; Guo, F.; Shi, M.; Meng, L.; Zhang, H.; Qiao, J.; Guo, Z.; Chen, C. Roles of p53 and ASF1A in the Reprogramming of Sheep Kidney Cells to Pluripotent Cells. Celular Reprogramming, 17: 441-452, 2015. 
Shirazi, A.; Heidari, M.; Shams-Esfandabadi, N.; Momeni, A.; Derafshian, Z. Overexpression of signal transducers and activators of transcription in embryos derived from vitrified oocytes negatively affect Ecadherin expression and embryo development. Cryobiology, 70: 239-245, 2015.

Silva, P.G.C. Análise interespecífica da expressão de genes relacionados à pluripotência durante o desenvolvimento embrionário. 2017. 72 f. Dissertação (Mestrado em Ciência Veterinária) Programa de Pós-Graduação em Ciência Veterinária, Universidade Federal Rural de Pernambuco.

Smith, A.G. Embryo-derived stem cells: of mice and men. Annual Review of Cell and Developmental Biology, 17: 435-462, 2001.

Song, G.; Satterfield, M.C.; Kim, J.; Bazer, F.W.; Spencer, T.E. Progesterone and interferon tau regulate leukemia inhibitory factor receptor and IL6ST in the ovine uterus during early pregnancy. Reproduction, 137 : 553-565, 2009.

Su, X.; Ling, Y.; Liu, C.; Meng, F.; Cao, J.; Zhang, L.; Zhou, H.; Liu, Z.; Zhang, Y. Isolation, Culture, Differentiation, and Nuclear Reprogramming of Mongolian Sheep Fetal Bone Marrow-Derived Mesenchymal Stem Cells. Cellular Reprogramming, 17: 288296, 2015.

Takahashi, K.; Yamanaka, S. Induction of pluripotent stem cells from mouse embryonic and adult fibroblast cultures by defined factors. Cell, 126: 663-676. 2006.

Takahashi, K.; Tanabe, K.; Ohnuki, M.; Narita, M.; Ichisaka, T.; Tomoda, K.; Yamanaka, S. Induction of pluripotent stem cells from adult human fibroblasts by defined factors. Cell, 131: 861-872, 2007.

Wang, J.; Rao, S.; Chu, J.; Shen, X.; Levasseur, D.N.; Theunissen, T.W.; Orkin, S.H. A protein interaction network for pluripotency of embryonic stem cells. Nature, 444: 364368, 2006.

Wang, Z.; Zhang, W.; Ji, J.L.; Gao, Q.X.; Xiao, S.H.; Wang, F. Effects of ghrelin on developmental competence and gene expression of in vitro fertilized ovine embryos, Theriogenology, 79: 695-701, 2013a.
Wang, L.H.; Zhang, W.; Ji, J.L.; Gao, Q.X.; Xiao, S.H.; Wang, F. Molecular characterization and expression analysis of the Lrh-1 gene in Chinese $\mathrm{Hu}$ sheep. Genetics and Molecular Research, 12: 1490-1500, 2013b.

Wang, X.; Niu, Y.; Zhou, J.; Yu, H.; Kou, Q.; Lei, A.; Zhao, X.; Yan, H.; Cai, B.; Shen, Q.; Zhou, S.; Zhu, H.; Zhou, G.; Niu, W.; Hua, J.; Jiang, Y.; Huang, X.; Ma, B.; Chen, Y. Multiplex gene editing via CRISPR/Cas9 exhibits desirable muscle hypertrophy without detectable off-target effects in sheep. Science Reports, 6(32271), 2016.

White, S.N.; Mousel, M.R.; Herrmann-Hoesing, L.M.; Reynolds, J.O.; Leymaster, K. A.; Neibergs, H.L.; Lewis, G.S.; Knowles, D.P. Genome-Wide Association Identifies Multiple Genomic Regions Associated with Susceptibility to and Control of Ovine Lentivirus, Plos One, 7(e47829), 2012.

Williams, S.H.; Sahota, V.; Palmai-Pallag, T.; Tebbutt, S.J.; Walker, J.; Harris, A. Evaluation of gene targeting by homologous recombination in ovine somatic cells. Molecular Reproduction and Development, 66: 115-125, 2003.

Wilmut, I.; Schnieke, A.E.; Mcwhir, J.; Kind, A.J.; Campbell, K.H. Viable offspring derived from fetal and adult mammalian cells. Nature, 385: 810-813, 1997.

Wilmut, I.; Beaujean, N.; De Sousa, P.A.; Dinnyes, A.; King, T.J.; Paterson, L.A.; Wells, D.N.; Young, L.E. Somatic cell nuclear transfer. Nature, 419: 583-586, 2002.

Wu, G.; Schöler, H.R. Role of Oct4 in the early embryo development. Cell Regeneration, 3(e7): 2014.

Yeo, J.C.; Ng, H.H. The transcriptional regulation of pluripotency. Cell Research, 23: 20-32, 2013.

Young, R.A. Control of the embryonic stem cell state. Cell, 144: 940-954, 2011.

Zeineddine, D.; Hammoud, A.A.; Mortada, M.; Boeuf, H.; Am, J. The Oct4 protein: more than a magic stemness marker. Stem Cells, 3: 74- 82, 2014.

Zwaka, T. P. Ronin and caspases in embryonic stem cells: a new perspective on regulation of the pluripotent state. Cold Spring Harbor Symposia on Quantitative Biology, 163: 163-169, 2008. 